\title{
Towards a Conceptual Template for Intellectual Capital Measurement and Reporting
}

\author{
$\mathrm{Yi} \mathrm{An}^{1}$, Umesh Sharma $^{2} \&$ Zhuquan Wang ${ }^{1}$ \\ ${ }^{1}$ College of Management, Ocean University of China, Laoshan District, Qingdao City, China \\ ${ }^{2}$ Waikato Management School, University of Waikato, Hamilton, New Zealand \\ Correspondence: Yi An, College of Management, Ocean University of China, 238 Songling Road, Laoshan \\ District, Qingdao City, China. E-mail: ryson9696@hotmail.com
}

Received: April 16, 2015

Accepted: April 27, 2015

Online Published: June 20, 2015

doi:10.5539/ijbm.v10n7p236

URL: http://dx.doi.org/10.5539/ijbm.v10n7p236

\begin{abstract}
In the current information age, Intellectual capital has become a type of critical resource that can create value as well as sustain a competitive advantage for firms. This paper reviews some key intellectual capital (IC) measurement and reporting models, comprising the Balanced Scorecard, Skandia Navigator Scheme, Intangible Assets Monitor, the DATI guideline, and the MERITUM project. Simultaneously, we synthesize these models to develop a conceptual template in the form of an IC statement, which can be used as a management tool for companies to measure and report their IC resources. It is expected that our paper should have some implications for companies and corporate reporting policy makers.
\end{abstract}

Keywords: intellectual capital, measurement, reporting, sustainable resource

\section{Introduction}

Due to the transition of our society from the industrial age to the information age, the focus on physical capital has diminished commensurate with an increased emphasis on intellectual capital (IC), such as intellectual property, brand, customers, business networks, employee competences etc., There is a growing acknowledgement that IC is a critical sustainable resource that can create value and sustain a competitive edge for organizations (An et al., 2011; Bismuth \& Tojo, 2008; Stewart, 1997; White, 2007).

The significance of IC has attracted the attention of many international institutions, accounting standard setters, government regulators, and academic researchers (e.g. OECD, 1999; FASB, 2001; DATI, 2003; Dumay, 2008). Further, they have initiated a series of movements to develop a number of IC measurement and reporting models (Bontis et al., 1999; Johanson et al., 2006). Amongst them, the most influential ones include three measurement models: the Balanced Scorecard, the Skandia Navigator Scheme, and the Intangible Assets Monitor; and two reporting models: the DATI guidelines, and the MERITUM project.

In this paper, we review the key IC measurement and reporting models, and synthesize them into a template taking the form of an IC statement, as a conceptual framework for firms to measure and report their IC. Albeit there have been some studies reviewing IC measurement or reporting models (e.g. Bontis, 2001; Chen et al., 2004; Levy \& Duffey, 2007; Abhayawansa, 2014), no prior research integrates these models to develop a thorough framework for IC measurement and reporting. Our paper therefore contributes to the extant literature in this respect. In the following section, the key IC measurement models are reviewed.

\subsection{Review of Key IC Measurement Models}

\subsubsection{The Balanced Scorecard (BSC)}

Kaplan and Norton (1992) developed a multi-dimensional measurement model for corporate performance called the "Balanced Scorecard" in the early 1990s. The model encourages firms to monitor their performance not only from the financial perspective, but also from some non-financial perspectives, such as customer, internal business process, and learning and growth. The four key perspectives are described as follows (Kaplan \& Norton, 1992).

- $\quad$ Financial perspective: this perspective gauges the profitability of an organization. 
- Customer perspective: this perspective identifies targeted customer and market segments and assesses the organization's success in these segments.

- Internal business process perspective: this perspective focuses on internal operations that further both the customer perspective by creating value for customers and the financial perspective by increasing shareholder value.

- $\quad$ Learning and growth perspective: this perspective identifies the capabilities the organization must excel at to achieve superior internal processes that create value for customers and shareholders. From this point, the four perspectives are interrelated one another through a cause-and-effect chain, eventually leading to financial results (namely create value for shareholders).

Based upon the four perspectives, a number of measures were developed in order to offer a more robust analysis of corporate performance (Bontis et al., 1999; Chen et al., 2004). Those measures are summarized in Table1.

Table 1. The BSC measures

\begin{tabular}{|c|c|}
\hline Perspectives & Measures \\
\hline Financial perspective & $\begin{array}{l}\text { Income measures: operating profit, gross margin percentage } \\
\text { Revenue and cost measures: revenue growth, revenues from new products, cost reductions in key areas } \\
\text { Income and investment measures: economic value added, return on investment }\end{array}$ \\
\hline Customer perspective & $\begin{array}{l}\text { Market share, customer satisfaction, customer-retention percentage, time taken to fulfil customers' requests, } \\
\text { number of customer complaints }\end{array}$ \\
\hline $\begin{array}{l}\text { Internal-business-process } \\
\text { perspective }\end{array}$ & $\begin{array}{l}\text { Innovation process: Operating capabilities, number of new products or services, new-product development } \\
\text { times and number of new patents } \\
\text { Operational process: yield, defect rates, time taken to deliver product to customers, percentage of on-time } \\
\text { deliveries, average time taken to respond to orders, set-up time, manufacturing downtime } \\
\text { Post-sales service process: time taken to replace or repair defective products, hours of customer training } \\
\text { for using the product }\end{array}$ \\
\hline $\begin{array}{l}\text { Learning-and-growth } \\
\text { perspective }\end{array}$ & $\begin{array}{l}\text { Employee measures: employee education and skill levels, employee-satisfaction ratings, employee turnover } \\
\text { rates, percentage of employee suggestions implemented, percentage of compensation based on individual } \\
\text { and team incentives } \\
\text { Technology measures: information system availability, percentage of processes with advanced controls }\end{array}$ \\
\hline
\end{tabular}

Source: Horngren et al. (2011, p. 601).

From the table, it can be found that the BSC combines both financial and non-financial measures from four perspectives in a coherent system to evaluate both short-run and long-run performance of a company, which widen the performance management lens (Bontis et al., 1999; Chen et al., 2004; Horngren et al., 2011). Moreover, three non-financial perspectives provide a set of specific measures that are related to intellectual capital. From this regard, the BSC can be employed as a model for IC measurement although it may not cover all the IC components. Firms should align the BSC to corporate strategy, especially in designing performance measures, so that it can facilitate the implementation of corporate strategy, and ultimately achieve financial success (Kaplan \& Norton, 1996; 2004). However, the BSC is not particularly designed for IC measurement. Its main purpose is to assist companies implant a (more) balanced and strategic performance measurement and management system (combining both financial and non-financial measures).

\subsubsection{Skandia Navigator Scheme (SNS)}

The Skandia Navigator Scheme, developed by Leif Edvinsson (the former director of intellectual capital in Skandia, a leading Swedish financial services company), is deemed to be a dynamic and holistic IC measurement model (Chen et al., 2004). It was designed to synthesise both financial and non-financial information into one report through "measuring hidden dynamic factors that underlie "the visible company of building and products"" (Bontis, 2001, p. 44). In the scheme, intellectual capital is classified into two categories: human capital and structure capital. In accordance with Skandia (1994), human capital refers to the knowledge and competences of employees within a company to provide solutions to its customers while structure capital, further categorized into customer capital and organizational capital, represents "what remains in the company when employees go home for the night" (Roos et al., 1997, p. 58), such as customer relationships, brands and reputation, management processes, information and networking systems, and so forth. Intellectual capital plus financial capital construct the total value of the company represented by market capitalization. 
In practice, the Navigator Scheme follows the BSC taking into account financial, operational and customer factors for performance measurement. But it is more explicit in which thirty-six key indicators were applied to measure five different 'focuses' of corporate performance: namely financial focus, customer focus, process focus, renewal and development focus, and human focus (Levy \& Duffey, 2007; Schneider, 2006; Bontis, 2001). Each focus has its own objective and set of indicators. Table 2 below provides a summary of the model.

Table 2. "Focus" of the skandia navigator scheme

\begin{tabular}{|c|c|c|}
\hline Focus & Objective & Key indicators \\
\hline Financial focus & $\begin{array}{l}\text { To measure income generated by the } \\
\text { committed intangible investment }\end{array}$ & $\begin{array}{l}\text { Revenues/employee, revenue from new customers/total } \\
\text { revenue, income/management assets, etc. }\end{array}$ \\
\hline Customer focus & $\begin{array}{l}\text { To assess the quality of the } \\
\text { relationship to customers and its } \\
\text { evolution }\end{array}$ & $\begin{array}{l}\text { Days spent visiting customers, ratio of sales contacts to } \\
\text { sales closed, number of customers gained versus lost, } \\
\text { index of satisfaction, etc. }\end{array}$ \\
\hline Process focus & $\begin{array}{l}\text { To measure the productivity of } \\
\text { information systems, the level of } \\
\text { equipment of the personnel and the } \\
\text { technical staff management }\end{array}$ & $\begin{array}{l}\text { Administrative expenses/total revenues, volatility-interest } \\
\text { rates, PCs/employee, processing time, etc. }\end{array}$ \\
\hline $\begin{array}{l}\text { Renewal and development } \\
\text { focus }\end{array}$ & $\begin{array}{l}\text { To assess the development of the } \\
\text { firm's capabilities, including its } \\
\text { human resources dimensions }\end{array}$ & $\begin{array}{l}\text { Competence development expense/employee, satisfied } \\
\text { employee index, marketing expense/managed assets, } \\
\text { marketing expense/customer, etc. }\end{array}$ \\
\hline Human focus & $\begin{array}{l}\text { To measure the performance of } \\
\text { human resources, comprising terms } \\
\text { of time allowance }\end{array}$ & $\begin{array}{l}\text { Managers with advanced degrees; annual turnover of } \\
\text { staff, leadership index, etc. }\end{array}$ \\
\hline
\end{tabular}

Source: adapted from Schneider (2006, p. 43).

All the indicators in the Skandia model are monitored on a yearly basis. The results (of the indicators) from various focuses are used to prepare an intellectual capital statement in order to "highlight the value creating process at Skandia and forms a basis for both business planning and management as well as for outside reporting" (Schneider, 2006, p. 44). Skandia developed the first internal IC statement in 1985 for better managing its intangibles, and in 1994 the company issued the first external IC statement as a supplement to the annual report, which made the IC-related information become accessible to its stakeholders (Bontis, 2001; Kaufimann \& Schneider, 2004).

Most academic researchers in the field acknowledge that Skandia makes considerable efforts to create a taxonomy for IC measurement, which has "emboldened others to look beyond traditional assumptions of what creates value for organizations" (Bontis, 2001, p. 47). The model is impressive in particular in recognizing the importance of customer capital for value creation of an organization; also, it provides a broad coverage of organizational structural and process indicators that have not been used before (Bontis, 2001; Chen et al., 2004). Skandia's approach is a multi-dimensional conceptualisation of organizational value, which makes the invisible assets become visible, and as a consequence provides a better picture of corporate performance (Bontis, 2001; Schneider, 2006).

Although the Skandia model is considered to be very helpful for firms to measure their IC, it has some drawbacks. Initially, Roos et al. (1997) argue that the model provides only a timely snapshot rather than dynamic flows of intellectual capital because of its heavy reliance on a balance sheet approach. Moreover, according to Huseman and Goodman (1999), it is not sensible that some indicators in relation to structural capital, such as PCs/employee, etc., are deemed to be drivers of value-creation since employees sitting in front of their computers do not necessarily signify they are investing their knowledge into their PCs, which can be translated into the firms' competitive advantage. In addition, Andriessen (2004) states that the extensive list of 36 indicators is too many to truly understand what is being measured for users, and it is difficult to determine the cause and effect from the model. Yet, given that the model is particularly designed for IC measurement, it can be regarded as a significant advancement in the area.

\subsubsection{Intangible Assets Monitor (IAM)}

The Intangible Assets Monitor (IAM) was developed by Karl-Eric Sveiby in Sweden. It is considered to be another influential model for IC measurement. In the model, Sveiby identifies three "families of intangible assets 
(or IC)" comprising internal structure, external structure and employee competence in addition to the visible equity represented by book value, which is the theoretical foundation for the IAM (refer to Table 3). According to Sveiby (1997), these three elements of intangible assets should be monitored and assessed principally by non-financial indicators in order to provide better management control.

Table 3. Composition of intangible assets

\begin{tabular}{|c|c|c|c|}
\hline & Intangible assets (or IC) & & \\
\hline Visible equity (book value) & Internal structure: & External structure: & Employee competence \\
\hline $\begin{array}{l}=\text { Tangible assets }- \text { visible } \\
\text { debt }\end{array}$ & $\begin{array}{l}\text { Including management } \\
\text { processes, legal structure, } \\
\text { intellectual property, culture, } \\
\mathrm{R} \& \mathrm{D} \text {, information systems, } \\
\text { etc. }\end{array}$ & $\begin{array}{l}\text { Including brands, reputation, } \\
\text { customer and supplier } \\
\text { relations, } \\
\text { collaborations etc. }\end{array}$ & $\begin{array}{l}\text { Including education, } \\
\text { experience, skills, etc. }\end{array}$ \\
\hline
\end{tabular}

Source: Adapted from Bontis (2001, p. 52).

As to the conceptual framework of IAM, it is composed of a three-by-three matrix (Schneider, 2006). The prior 'three' represents the three elements of intangible assets while the later 'three' refers to three general measurement indicators proposed by Sveiby (1997): growth/renewal, efficiency, and stability (refer to Table 4). In operation, each component of intangible assets is assessed in the light of the three indicators.

Table 4. The intangible assets monitor matrix

\begin{tabular}{lll}
\hline The Intangible Assets Monitor & & \\
\hline Internal Structure & External Structure & Employee competence \\
\hline Indicators of growth/renewal & Indicators of growth/renewal & Indicators of growth/renewal \\
Indicators of efficiency & Indicators of efficiency & Indicators of efficiency \\
Indicators of stability & Indicators of stability & Indicators of stability \\
\hline
\end{tabular}

Source: Schneider (2006, p. 45).

Each general indicator consists of some specific indices for measuring each element of intangibles, which are summarized in Table 5 .

Table 5. Indices in the intangible assets monitor

\begin{tabular}{|c|c|c|c|}
\hline \multirow[t]{2}{*}{ Intangible Assets } & \multicolumn{3}{|l|}{ Indices } \\
\hline & Growth/Renewal & Efficiency & Stability \\
\hline Internal Structure & $\begin{array}{l}\text { Investment in the internal } \\
\text { structure, investment in } \\
\text { information } \\
\text { systems, processing } \\
\text { contributing to internal } \\
\text { structure }\end{array}$ & $\begin{array}{l}\text { Proportion of support staff, } \\
\text { sales per support } \\
\text { values } \\
\text { measurements }\end{array}$ & $\begin{array}{l}\text { Age of the organization, } \\
\text { support staff turnover, the } \\
\text { rookie ratio }\end{array}$ \\
\hline External Structure & $\begin{array}{l}\text { Profitability per customer, } \\
\text { organic growth }\end{array}$ & $\begin{array}{l}\text { The satisfied customer index, } \\
\text { win/loss index, sales per } \\
\text { customer }\end{array}$ & $\begin{array}{l}\text { Proportion of big customers, } \\
\text { age structure, devoted } \\
\text { customers ratio, frequency of } \\
\text { repeat orders }\end{array}$ \\
\hline Employee Competence & $\begin{array}{l}\text { Number of years in the } \\
\text { profession, education level, } \\
\text { training and education costs, } \\
\text { grading of executives, } \\
\text { professional turnover, } \\
\text { competence-enhancing } \\
\text { customers. }\end{array}$ & $\begin{array}{l}\text { Proportion of professionals in } \\
\text { the company, the leverage } \\
\text { effect of professionals, } \\
\text { value-added per professional }\end{array}$ & $\begin{array}{l}\text { Average age, seniority, } \\
\text { relative pay position, } \\
\text { professional turnover rate }\end{array}$ \\
\hline
\end{tabular}

Source: Adapted from Bontis (2001, p. 53). 
To sum up, the IAM is another model particularly designed for IC measurement. In describing it, Bontis (2001, p. 52) states:

In essence, the intangible assets monitor is 'a presentation format that displays a number of relevant indicators in a simple fashion' (Sveiby, 1997, 197). The choice of indicators depends on the company's strategy but should include only a few of the measurement indicators for each intangible asset with the most important areas needing to be covered those of growth and renewal, efficiency, and stability. The IAM can be integrated into the management information system. And lastly, it should not exceed one page in length but should be accompanied by a number of comments.

Comparing with BSC and SNS, the IAM is deemed to be more advanced since it clearly identifies three elements of IC as well as provides a series of indices associated with these three elements, whereas other two models only provide indicators with different "perspectives" or "focuses". Therefore, the IAM can be seen as a highly developed IC measurement model. Moreover, the identified three-element framework of IC (internal, external structure and employee competence) is widely accepted and applied by researchers in the area. In this paper, we also use it as a basic framework to develop a template for IC measurement and reporting.

\subsection{Review of Key IC Reporting Models}

\subsubsection{The DATI Guideline}

The DATI guideline was issued by the Danish Agency for Trade and Industry (head office of the Danish Ministry of Science, Technology and Innovation) in 2003 for the purpose of providing a general framework for the development of an external IC statement in Denmark (Danish Agency for Trade and Industry, 2003). The development of the guideline was based upon experiences of 17 Danish firms for IC disclosure as a result of a governmental initiative into IC reporting (Bukh \& Johanson, 2003; Schneider, 2006).

In accordance with the DATI guidelines, an intellectual capital statement (ICS) consists of four elements: a knowledge narrative, a set of management challenges, a set of initiatives, a set of indicators, all of which jointly present the strategies and efforts of a company in IC management through text, figures, and illustrations (Danish Agency for Trade and Industry, 2003; Schneider, 2006). Table 6 below demonstrates the four elements in detail.

Table 6. Elements of an intellectual capital statement

\begin{tabular}{|c|c|c|}
\hline Element & Description & Key points (questions) \\
\hline Knowledge narrative & $\begin{array}{l}\text { A narrative regarding the company's } \\
\text { ambition to create and increase use-value of } \\
\text { its products and services for its customers } \\
\text { and the types of knowledge resources } \\
\text { required to accomplish it. }\end{array}$ & $\begin{array}{l}\text { - What products or services does the } \\
\text { company offer? } \\
\text { - How does it make a difference for the } \\
\text { users? } \\
\text { - What knowledge resources are } \\
\text { necessary to supply the products or services? }\end{array}$ \\
\hline Management challenges & $\begin{array}{l}\text { The challenges posed by the role of } \\
\text { knowledge resources in the firm's business } \\
\text { model. }\end{array}$ & $\begin{array}{l}\text { - How are the knowledge resources } \\
\text { related? } \\
\text { - Which existing knowledge resources } \\
\text { need to be strengthened? } \\
\text { - What new knowledge resources are } \\
\text { required? }\end{array}$ \\
\hline initiatives & $\begin{array}{l}\text { The efforts to compose, develop and procure } \\
\text { knowledge resources. }\end{array}$ & $\begin{array}{l}\text { - What initiatives, actual and potential, } \\
\text { can be identified? } \\
\text { - What initiatives should be given } \\
\text { priority? }\end{array}$ \\
\hline Indicators & $\begin{array}{l}\text { The mechanisms of monitoring the portfolio, } \\
\text { development and the effects of knowledge } \\
\text { resources. }\end{array}$ & $\begin{array}{l}\text { - Effects: how do activities work? } \\
\text { - Activities: what does the company do } \\
\text { to upgrade knowledge resources? } \\
\text { - Resource Mix: what is the } \\
\text { composition of knowledge resources? }\end{array}$ \\
\hline
\end{tabular}

Source: Adapted from Mouritsen et al. (2005, p. 32).

In short, the "knowledge narrative" explains how a firm uses its knowledge resources to create and enhance the 
'use value' of its products and services for customers; the "management challenges" highlight the knowledge resources, such as employees, customers, and processes, which need to be strengthened through in-house development or outsourced; the "initiatives" refer to a firm's efforts to obtain, develop and combine knowledge resources; and the 'indicators' are concerned with how to monitor the initiatives (Johanson et al., 2006). The four elements are interrelated in function, and finally form an IC statement. In describing the relationships between the elements, Johanson et al. (2006, p. 482) state that:

The indicators show how initiatives are launched and put into effect. The initiatives formalize the problems identified as management challenges. The challenges single out what has to be done if knowledge resources are to be developed. The knowledge narrative also sums up, communicates and re-orientates what the company's skills and capacity do or must do for customers. And which knowledge resources are needed within the company. Once fully completed, the analysis can be presented in the intellectual capital statement.

\subsubsection{The Meritum Project}

The full name of MERITUM is "measuring intangibles to understand and improve innovation management". It is a project created and financially sponsored by the European Commission in the late 1990s. A collaboration of 40 academic researchers in the field of intangibles from six European countries (Denmark, Finland, France, Norway, Spain, and Sweden) is involved in the project. The primary objective of the project is "to produce guidelines to measure and disclose intangibles for the purpose of improving decision making for managers and stakeholders" (Petty \& Guthrie, 2000, p. 163). In addition, the project has three other themes: establishing a classification scheme for intangibles, documenting company management and control systems for identifying best practices inside European firms involved in the measurement of investments on intangible resources, and assessing the relevance of intangibles in the functioning of capital markets by means of market data analysis (Johanson et al., 2006; Petty \& Guthrie, 2000).

The output of the MERITUM project is a proposed guideline for external disclosure of intellectual capital, which can be divided into three sections as demonstrated in Table 7.

Table 7. Three sections of the MERITUM guideline

\begin{tabular}{ll}
\hline Sections of Guideline & Contents \\
\hline Conceptual Framework & Definition of Basic concepts: \\
& Intangible resources, IC, human capital, structure capital, \\
& relational capital \\
& Relationship between measurement and reporting and \\
Management of Intangibles & management is addressed through: \\
& 1) steps to be followed (formulating the vision of the firm, \\
identifying and measuring critical intangibles) \\
2) supporting processes to transform measurement and \\
disclosure into managerial action \\
Elements contained in the report: \\
1) the vision of the firm \\
2) a summary of intangible resources and activities \\
3) a system of indicators
\end{tabular}

Source: Adapted from Bukh and Johanson (2003, p. 579).

According to Johanson et al. (2006), the MERITUM guideline is an outcome from a number of theoretical and empirical research projects in relation to management control, capital market and classification issues, and it can be applied as an IC management tool for companies. Alone with the DATI guideline, both provide a well-established framework for IC reporting.

\section{A Synthesis}

In review of the key IC measurement and reporting models, it is noted that these models are interrelated, and sometimes overlap. So, we believe that the models can be synthesized to provide a more comprehensive framework for IC measurement and reporting. However, the purpose of this paper is to provide a conceptual framework (or template) rather than very detailed guidelines for IC measurement and reporting.

In the development of the framework, the basic concept is that, the measurement models (BSC, SNS and IAM) 
provide options for key IC performance indicators (KPIs) whilst the reporting models (DATI and MERITUM) provide formats for an IC statement. Of course, the selected KPIs and the reporting format should be tightly related to corporte strategy. In addition, the vision of a company and the accountability to various stakeholders should be also considered (refer to figure 1 for the development of the conceptual framework).

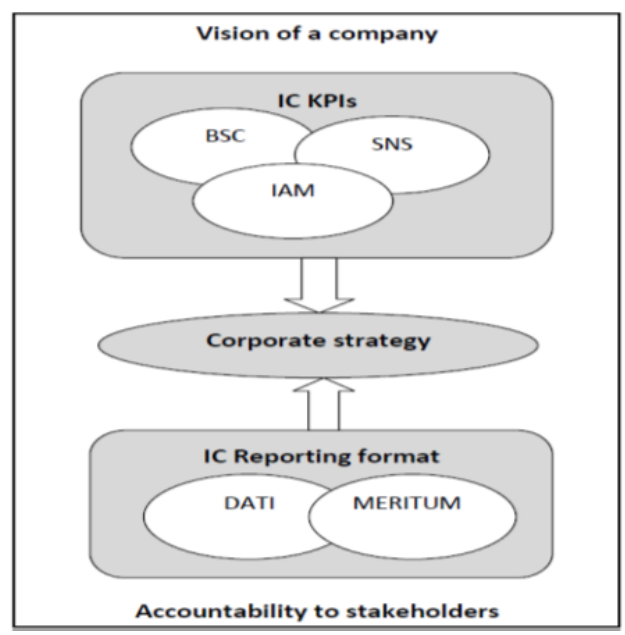

Figure 1. The development of the conceptual framework

Based upon the above concepts, we synthesize the previous key IC measurement and reporting models, and propose a new conceptual template in the form of an IC statement (see below), which can be used as a management tool for companies to measure and report their IC resources.

\subsection{The Conceptual Template}

\section{Introduction}

1.1 The background of the company

1.2 The adopted IC framework: including the definitions of IC and its components, as well as relationships between the components

\subsection{Vision/mission statement}

1.4 The objectives of the report

2. Internal structure statement

2.1A summary of internal capital resources, challenges and activities

2.2 Key performance indicators (KPIs) regarding internal capital (Note 1)

3. External structure statement

3.1A summary of external capital resources, challenges and activities

3.2 Key performance indicators regarding external capital

4. Employee competence statement

4.1A summary of human capital resources, challenges and activities

4.2 Key performance indicators regarding human capital

\section{Potential benefits of IC}

Including a general discussion with regard to how three elements of IC (internal, external and employee) relate and complement in creating value for corporate growth, strategic management (competence), stakeholder relationships and financial results (future cash flows)

\section{Notes}

Including discussion of relevant accounting policies, and the explanation of some IC KPIs

In addition, the following principles should be followed in the framework: 
- $\quad$ Easy to prepare (not very costly)

- Include both qualitative and quantitative information, using narratives (Note 2) and pictures for the presentation of qualitative information

- Should be high quality: relevance, reliability, clarity, materiality, completeness, substance, gross measurements, neutrality, comparability (Deegan and Samkin, 2009)

- Not necessary to disclose sensitive information, such as business secrets, prior-registration patents, and critical value-creating processes.

- Avoid an exhaustive list of IC KPIs: firms should choose the most appropriate KPIs in the light of their own situations or strategic needs.

- $\quad$ Easy to understand

- From a stakeholder perspective rather than focusing on shareholders only

\section{Concluding Remarks}

As a type of sustainable resource, intellectual capital measurement, management and reporting are critical for organization to achieve sustainable development. In this paper, we make contributions through synthesizing the key IC measurement and reporting models to develop a conceptual template, taking the form of an IC statement. The proposed IC statement can be used as a framework for organizations to measure, manage and report their IC attributes. It is encouraged that organizations should issue such a statement annually (stand-alone or as a supplement to the corporate annual report). This would enable various stakeholders to obtain a better picture as to the IC base of the company, the activities of the company employing IC to create value, and the output of the activities. As a consequence, it could enhance the confidence of stakeholders on the company, gain more support from them, and attain more funding opportunities from investors in the capital markets or financial institutions (An et al., 2011).

Our research has several implications for companies and corporate reporting policy makers (or regulators). First, companies can employ the template as a reference to develop their own IC statements for the purpose of internal or external management. Furthermore, corporate reporting policy makers (or regulators) can apply the template as a basis to guide publicly listed companies to report their IC-related information so as to assist investors better assess these companies' performance and potential.

\section{Acknowledgements}

The authors thank the comments offered by Professor James Guthrie (Macquarie University) and Professor Howard Davey (University of Waikato). This research was supported by the National Natural Science Foundation of China (No. 71172099).

\section{References}

Abhayawansa, S. A. (2014). A review of guidelines and frameworks on external reporting of intellectual capital. Journal of Intellectual Capital, 15(1), 100-141. http://dx.doi.org/10.1108/JIC-04-2013-0046

An, Y., Davey, H., \& Eggleton, I. R. C. (2011). Towards a comprehensive theoretical framework for voluntary IC disclosure. Journal of Intellectual Capital, 12(4), 571-585. http://dx.doi.org/10.1108/14691931111181733

Andriessen, D. (2004). Making sense of intellectual capital: designing a method for the valuation of intangibles. Amsterdam: Elsevier Butterworth-heinemann.

Bismuth, A., \& Tojo, Y. (2008). Creating value from intellectual capital. Journal of Intellectual Capital, 9(2), 228-245. http://dx.doi.org/10.1108/14691930810870319

Bontis, N. (2001). Assessing knowledge assets: A review of the models used to measure intellectual capital. International Journal of Management Reviews, 3(1), 41-60. http://dx.doi.org/10.1111/1468-2370.00053

Bontis, N., Dragonetti, N. C., Jacobsen, K., \& Roos, G. (1999). The knowledge toolbox: A review of the tools available to measure and manage intangible resources. European Management Journal, 17(4), 15-27. http://dx.doi.org/10.1016/S0263-2373(99)00019-5

Bukh, P. N., \& Johanson, U. (2003). Research and knowledge interaction: Guidelines for intellectual capital reporting. Journal of Intellectual Capital, 4(4), 576-587. http://dx.doi.org/10.1108/13683040410524739

Chen, J., Zhu, Z., \& Xie, H. Y. (2004). Measuring intellectual capital: a new model and empirical study. Journal of Intellectual Capital, 5(1), 195-212. http://dx.doi.org/10.1108/14691930410513003 
Danish Agency for Trade and Industry (DATI). (2003). Intellectual Capital Statements-the new guidelines. Copenhagen: Danish Ministry of Science, Technology and Innovation.

Deegan, C., \& Samkin, G. (2009). New Zealand Financial Accounting. North Ryde, New South Wales, Australia: McGraw-Hill.

Dumay, J. C. (2008). Narrative disclosure of intellectual capital: A "structurational" analysis. Management Research News, 31(7), 518-537. http://dx.doi.org/10.1108/01409170810876080

FASB. (2001). Improving business reporting: Insights into enhancing voluntary disclosures. Steering Committee Business, Reporting Research Project, Financial Accounting Standard Board, US.

Horngren, C. T., Wynder, M., Maguire, W., Tan, R., Datar, S. M., Foster, G., Rajan, M. V., \& Ittner, C. (2011). Cost accounting: A managerial emphasis. Frenchs Forest, New South Wales: Pearson Australia.

Huseman, R., \& Goodman, J. (1999). Leading with knowledge. London: Sage.

Johanson, U., Koga, C., Skoog, M., \& Henningsson, J. (2006). The Japanese Government's intellectual capital reporting guideline: What are the challenges for firms and capital market agents? Journal of Intellectual Capital, 7(4), 474-491. http://dx.doi.org/10.1108/14691930610709121

Kaplan, R. S., \& Norton, D. P. (1992). The balance scorecard-measures that drives performance. Harvard $\begin{array}{llll}\text { Business } & \text { Review, } & \text { 71-79. }\end{array}$ https://hbr.org/2005/07/the-balanced-scorecard-measures-that-drive-performance/ar/1

Kaplan, R. S., \& Norton, D. P. (1996). The Balanced Scorecard-translating strategy into action. Boston, US: Harvard Business School Press.

Kaplan, R. S., \& Norton, D. P. (2004). The strategy map: Guide to aligning intangible assets. Strategy \& Leadership, 32(5), 10-17. http://dx.doi.org/10.1108/10878570410699825

Kaufmann, L., \& Schneider, Y. (2004). Intangibles: A synthesis of current research. Journal of Intellectual Capital, 5(3), 366-387. http://dx.doi.org/10.1108/14691930410550354

Levy, F., \& Duffey, M. R. (2007). A review of existing methods to quantify intangible assets. International Journal of Accounting, Auditing and Performance Evaluation, 4(4/5), 382-399. http://dx.doi.org/10.1504/IJAAPE.2007.017085

Mouritsen, J., Bukh, P. N., \& Bang, H. K. (2005). Understanding intellectual capital in an innovative medium-sized firm: The case of Maxon Telecom. Australian Accounting Review, 15(2), 30-39. http://dx.doi.org/10.1111/j.1835-2561.2005.tb00290.x

OECD. (1999). Symposium on measuring and reporting intellectual capital: Experience, issues and prospects. Paris: OECD.

Petty, R., \& Guthrie, J. (2000). Intellectual capital literature review: measurement, reporting and management. Journal of Intellectual Capital, 1(2), 155-176. http://dx.doi.org/10.1108/14691930010350800

Roos, J., Roos, G., Dragonetti, N., \& Edvinsson, L. (1997). Intellectual capital: Navigating in the new business landscape. London: MacMillian Business.

Schneider, A. (2006). Intellectual capital reporting by the New Zealand Local Government Sector. Unpublished master thesis, University of Waikato, Hamilton, New Zealand.

Skandia Insurance Company. (1994). Visualizing intellectual capital at Skandia. Supplement to Skandia's 1994 annual report. Stockholm, Swede: Federation of Swedish Industries.

Stewart, T. A. (1997). Intellectual Capital: The new wealth of organizations. New York: Doubleday Dell Publishing Group, Inc.

Sveiby, K. E. (1997). Intangible assets monitor. Journal of Human Resources Costing and Accounting, 2(1), 73-97. http://dx.doi.org/10.1108/eb029036

White, L. N. (2007). Unseen measures: The need to account for intangibles. The Bottom Line: Managing Library Finances, 20(2), 77-84. http://dx.doi.org/10.1108/08880450710773011

\section{Notes}

Note 1 . The selection of IC KPIs can be primarily based upon the three key measurement models. 
Note 2. Since the narrative format has a "plot" that could facilitate various stakeholders who do not have much knowledge regarding IC to understand the IC-related activities (Dumay, 2008).

\section{Copyrights}

Copyright for this article is retained by the author(s), with first publication rights granted to the journal.

This is an open-access article distributed under the terms and conditions of the Creative Commons Attribution license (http://creativecommons.org/licenses/by/3.0/). 